J. Kyushu Dent. Soc. 53 ( 4 ) : 472 492, 1999.

\title{
The Effect of Zinc on Condylar Cartilage at Growth Stage
}

\author{
Hiroshi Ideguchi, Wenyu Dai, Ikuko Nishida, \\ Akiko Morimoto and Takahiro Nishioka \\ Department of Pediatric Dentistry (Director: Prof. Mitsutaka Kimura) \\ Kyushu Dental College, Kitakyushu, Japan
}

Accepted on June 25, 1999

To examine the effects of zinc on bone formation by endochondral ossification at growth stage, forty 5-week-old Wistar male rats, corresponding to childhood in humans, were randomly divided into 4 groups. In the control group, rats were fed on a standard diet. In the experimental groups, the rats were fed on no-zinc-component (zinc-deficient) diet, $50 \%$ low-zinc diet and $150 \%$-high-zinc diet respectively. After 4 weeks of feeding, all the rats were sacrificed and their condyles were observed as follows.

In the densitometric measurement, the zinc-deficient group showed the lower value than the other three groups $(\mathrm{p}<0.01)$.

In the microanalysis, there was a significant difference in the content of $\mathrm{Ca}$ or $\mathrm{P}$ between the zinc-deficient group and the other three groups $(p<0.01)$. The high-zinc group showed the significantly higher content of $\mathrm{Ca}$ and lower content of $\mathrm{P}$ than the other three groups $(\mathrm{p}$ $<0.01)$.

Compared with the control group on the histopathological findings, the zinc-deficient group showed the decreased cartilage cells in resting zone and zone of proliferation with the deformed shape. In zone of hypertrophy appeared the decreased calcified matrix, which were surrounded by the increased cartilag cells. The erosion of calcified matrix by the multinuclear chondroclasts tended to decrease. In zone of subchondral bone formation appeared the thinner trabeculae. Compared with the zinc-deficient group, the low-zinc group showed the increased erosion findings of the calcified matrix, surrounded by the increased hypertrophic chondrocytes, could be observed frequently. The subchondral bone formation was improved, but the trabeculae were thinner. Compared with the control group, the highzinc group showed the increase of both the calcified matrix surrounded by the hypertrophic chondrocytes and the erosion of the calcified matrix by the increased chondroclasts could be often seen. In zone of subchondral bone formation the differentiation of chondrocytes into bone cells was improved, leading to the successive and thick bone trabeculae in a vertical arrangement.

Compared with the control group on the scanning electron microscopic findings, the zincdeficient group showed the thinner bone trabeculae and the decrease of the longitudinal matrix in cartilage lacunae, on the wall of which appeared the calcareous globes in a sparse arrangement and the collective collagen fibers. On the surface of bone matrix formation, collagen fibers arranged sparsely and were in an irregular alignment, where the calcareous 
The Effect of Zinc on Condylar Cartilage at Growth Stage (Ideguchi et al.) - $473-$

microdepositions were present. The low-zinc group showed the thickker bone trabeculae than the zinc-deficient group. In the cartilage lacunae arranged the uncalcified globes, where the collagen fibers were often seen crossed into networks. On the bone formation surface appeared many collagen fiber bundles in a regular alignment, and on the superficial part the collagen fibers were clearly seen crossed into networks, the same as the findings in the control group. Upon the examination of an overall image in the high-zinc group, compared with the control group, the cartilage development from the growing cartilage layer to the following thick bone trabeculae was improved.

These results suggested that zinc, an essential trace element, had a positive effect on bone formation by endochondral ossification in the condyles of the growing rats.

Key words: Zinc/Condylar cartilage/Growth stage

\section{Introduction}

Bone mainly consists of calcium and protein, so it seems important for the individuals at growth spurt to get well-balanced nutrition. In normal individuals, peak bone mass is obtained at 17-20 years of age and thereafter a decrease with age occurs in both $\operatorname{sex}^{11}$. Maximizing the accumulation of bone mass is one of the most important aims in the prevention of bone loss resulting from aging. We have reported a series of studies ${ }^{2-10)}$ on clarifying the relationships between bone mass and dietary treatments, administration of physiological active factors, physical activity and so on. Recently, trace elements have been known to have an effect on bone formation and zinc has attracted our attention. Zinc is one of the components of many kinds of enzymes, such as carbonate dehydratase. Zinc deficiency readily results in loss of appetite, growth retardation, dermal lesions like keratosis and retardation of healing the wound ${ }^{11-14}$. It also has been reported that zinc deficiency in growing rats produced the sudden stop of growth and development ${ }^{15)}$. Zinc plays a positive role in bone metabolism, and zinc deficiency caused the decrease of alkaline phosphatase activity, causing incomplete bone formation ${ }^{16,17)}$.

In this study, we observed the condylar cartilage in the growing rats, which were given the diets with the different zinc levels, to determine the effect of zinc on bone formation at growth stage.

\section{Materials and Methods}

Forty 5-week-old Wistar male rats were randomly divided into 4 groups as follows. In the control group, rats were fed on a standard diet with tap water. In the zinc-deficient experimental group, rats were fed on a no-zinc-component diet with distilled water. In the low-zinc experimental group, rats were fed on a low zinc diet (zinc component is $50 \%$ of the standard diet) with tap water. In the high-zinc experimental group, rats were fed on a high zinc diet (zinc component is $150 \%$ of the standard diet) with tap water. All the rat food was made by Oriental Yeast (Tokyo, Japan). 
Table 1-1 Composition of experimental diets

\begin{tabular}{l|c|c|c}
\hline \multicolumn{1}{c|}{ Ingredient } & Standard diet & Low-Zn diet & High-Zn diet \\
\hline$\beta$-corn starch & 38.0 & 38.0 & 38.0 \\
Vitamin-free casein & 25.0 & 25.0 & 25.0 \\
$\alpha$-potato starch & 10.0 & 10.0 & 10.0 \\
Cellulose powder & 8.0 & 8.0 & 8.0 \\
Soy bean oil & 6.0 & 6.0 & 6.0 \\
Mineral mixture & $6.0^{\text {出 }}$ & $6.0^{\star}$ & $6.0^{\text {出 }}$ \\
Granulated sugar & 5.0 & 5.0 & 5.0 \\
Vitamin mixture & 2.0 & 2.0 & 2.0 \\
\hline \multicolumn{1}{c}{ ZnCO3 } & & & $3.26 \mathrm{mg} / 100 \mathrm{~g}$ \\
\hline
\end{tabular}

4. Standard mineral mixture

$\star$ : Low-Zn mineral mixture

Table 1-2 Composition of mineral mixture

$(\mathrm{g} / 100 \mathrm{~g})$

\begin{tabular}{l|c|c}
\hline \hline \multicolumn{1}{c|}{ Ingredient } & Standard mineral mixture & Low-Zn mineral mixture \\
\hline $\mathrm{CaHPO}_{4} \cdot 2 \mathrm{H}_{2} \mathrm{O}$ & 14.56 & 14.56 \\
$\mathrm{KH}_{2} \mathrm{PO}_{4}$ & 25.72 & 25.72 \\
$\mathrm{NaH}_{2} \mathrm{PO}_{4}$ & 9.35 & 9.35 \\
$\mathrm{NaCl}$ & 4.66 & 4.66 \\
$\mathrm{Ca}-$ lactate & 35.09 & 35.09 \\
$\mathrm{Fe}-$ citrate $_{\mathrm{MgSO}_{4}}$ & 3.18 & 3.18 \\
$\mathrm{ZnCO}_{3}$ & 7.17 & 7.17 \\
$\mathrm{MnSO}_{4} \cdot 4 \sim 5 \mathrm{H}_{2} \mathrm{O}$ & 0.11 & 0.055 \\
$\mathrm{CuSO}_{4} \cdot 5 \mathrm{H}_{2} \mathrm{O}$ & 0.12 & 0.12 \\
$\mathrm{~K}$ & 0.03 & 0.03 \\
Cellulose & 0.01 & 0.01 \\
\hline
\end{tabular}

The components of the diets were presented in Table 1.

After 4 weeks of feeding, all the rats were sacrificed under pentbarbital natrium. Their condyles were removed and later treated for densitometric measurement, microanalysis for $\mathrm{Ca}$ and $\mathrm{P}$, light-microscopic observations, and scanning electron microscopic observations. The animals were handled with adherence to the principles on the performance of experimental animals outlined by Kyushu Dental College.

\section{Densitometric measurement}

The condyles were kept in $10 \%$ neutral buffered formalin solution. These samples were imaged with Softex CSM (Softex Co, Tokyo, Japan) at $28 \mathrm{kVp}, 6 \mathrm{~mA}, 60 \mathrm{~s}$ and focus-film distance of $70 \mathrm{~cm}$ with Fuji softex film FG (Fuji Film Co, Tokyo, Japan) and aluminum reference wedge attached. The films were scanned by Microphotometer (Densitometer PDS- 
15, Konica, Tokyo, Japan). The survey light passed from the top of the condyle to the bottom border of the mandible and scanning was carried out with the slit of $10 \times 500 \mu \mathrm{m}$.

\section{Sample preparation for microanalysis for $\mathrm{Ca}$ and $\mathrm{P}$}

The samples were cut longitudinally at the site, $5 \mathrm{~mm}$ in front to the outer line of the condyles. After being fixed in $10 \%$ neutral buffered formalin solution, these samples were dehydrated through a graded ethanol series and treated in 2-methyl- $\alpha$-propanol, dried in tbutyl-alcohol by freeze-drying (ID-2, JEOL Ltd, Tokyo, Japan). Sections were embedded in resin, then abraded, polished, and sputtered with aurum. Later they were observed under a scanning microscope (JSM T-300, JEOL) equipped with energy-dispersive X-ray microanalysis (JED-2000, JEOL). Point analysis was performed to determine the content of $\mathrm{Ca}$ and $\mathrm{P}$.

\section{Sample preparation for light microscopy}

The samples were cut longitudinally at the site, $5 \mathrm{~mm}$ in front to the outer line of the condyles. After being fixed in $10 \%$ neutral buffered formalin solution, these samples were decalcified in $5 \%$ nitric acid solution for $24 \mathrm{~h}$, dehydrated through a graded ethanol series, and embedded in paraffin (Fisher Scientific, USA). Continuous cut specimen, $7 \mu \mathrm{m}$ of thickness, was made, stained with hematoxylin and eosin, and then observed under a light microscope.

\section{Samples preparation for scanning electron microscopy}

The samples were cut the same as those in preparation for microanalysis for $\mathrm{Ca}$ and $\mathrm{P}$, and fixed with $2.5 \%$ glutaraldehyde for $1 \mathrm{~h}$ after being cleaned with phosphate buffer ( $\mathrm{pH} 7.2$ ) by supersonic vibration to eliminate adhesion. They were rinsed by phosphate buffer (pH 7.2) before postfixation. Postfixation was performed in $1 \%$ osmic acid buffer solution (pH 7.2) under $4{ }^{\circ} \mathrm{C}$ for $2 \mathrm{~h}$. After fixation, these samples were dehydrated through a graded ethanol series, treated with 2-methyl- $\alpha$-propanol, dried in t-butyl alcohol by freeze-drying (ID-2, JEOL). Specimens were sputter-coated with gold and later observed under a scanning electron microscope (JSM T-300, JEOL).

\section{Results}

\section{Densitometric measurement}

The results of densitometric measurement in the control group $(1.00 \mathrm{~mm})$, zinc-deficient experimental group $(0.50 \mathrm{~mm})$, low-zinc experimental group $(1.00 \mathrm{~mm})$, and high-zinc experimental group $(1.00 \mathrm{~mm})$ are presented in Table $2-1$. There were significant differences between the zinc deficient experimental group and the other three groups. $(\mathrm{p}<0.01)$. The zinc deficient experimental group showed the low value (Table 2-2).

\section{Microanalysis for $\mathrm{Ca}$ and $P$}

The contents of $\mathrm{Ca}$ and $\mathrm{P}$ in all the groups are presented in Table $3-1$ and $3-2$. There is 
Table 2-1 Density of mandibular condyle in the equivalent aluminum

\begin{tabular}{c|c|c|c|c}
\hline \hline Control group & $\begin{array}{c}\text { Zn-deficient diet } \\
\text { group }\end{array}$ & $\begin{array}{c}\text { Low-Zn diet } \\
\text { group }\end{array}$ & $\begin{array}{c}\text { High-Zn diet } \\
\text { group }\end{array}$ \\
\hline $\mathrm{Al}$ & $1.00 \pm 0.03$ & $0.50 \pm 0.03$ & $1.00 \pm 0.03$ & $1.00 \pm 0.02$ \\
\hline
\end{tabular}

Table 2-2 Density of mandibular condyle in the equivalent aluminum

\begin{tabular}{c|c|c|c|c|c|c}
\hline \hline & $1-2$ & $1-3$ & $1-4$ & $2-3$ & $2-4$ & $3-4$ \\
\hline $\mathrm{Al}$ & $* *$ & - & - & $* *$ & $* *$ & - \\
\hline
\end{tabular}

1: Control group

2: Zn-deficient diet group

3: Low-Zn diet group

4: High-Zn diet group

Table 3-1 Analysis of the $\mathrm{Ca}$ and $\mathrm{P}$ of mandibular condyle by $\mathrm{X}$-ray microanalyzer (\%)

\begin{tabular}{c|c|c|c|c}
\hline \hline & Control group & $\begin{array}{c}\text { Zn-deficient diet } \\
\text { group }\end{array}$ & $\begin{array}{c}\text { Low-Zn diet } \\
\text { group }\end{array}$ & $\begin{array}{c}\text { High-Zn diet } \\
\text { group }\end{array}$ \\
\hline $\mathrm{Ca}$ & $56.10 \pm 0.66$ & $54.30 \pm 0.73$ & $55.53 \pm 0.32$ & $57.15 \pm 0.87$ \\
\hline $\mathrm{P}$ & $43.90 \pm 0.66$ & $45.70 \pm 0.64$ & $44.47 \pm 0.43$ & $42.85 \pm 0.99$ \\
\hline
\end{tabular}

Mean \pm S. D.

Table 3-2 Difference of the $\mathrm{Ca}$ and $\mathrm{P}$ of mandibular condyle by $\mathrm{X}$-ray microanalyzer

\begin{tabular}{c|c|c|c|c|c|c}
\hline \hline & $1-2$ & $1-3$ & $1-4$ & $2-3$ & $2-4$ & $3-4$ \\
\hline $\mathrm{Ca}$ & $* *$ & - & $* *$ & $* *$ & $* *$ & $* *$ \\
\hline $\mathrm{P}$ & $* *$ & - & $* *$ & $* *$ & $* *$ & - \\
\hline
\end{tabular}

$1:$ Control group

2: Zn-deficient diet group

3: Low-Zn diet group

4: High-Zn diet group

no significant difference in the contents of $\mathrm{Ca}$ or $\mathrm{P}$ between the low-zinc experimental and the control group. The zinc-deficient experimental group showed the lower content of Ca or the higher content of $\mathrm{P}$ than the other three groups, and there is a significant difference between the zinc-deficient experimental group and the other three groups $(p<0.01)$. The high-zinc experimental group showed the higher content of $\mathrm{Ca}$ or the lower content of $\mathrm{P}$ than 
The Effect of Zinc on Condylar Cartilage at Growth Stage (Ideguchi et al.) - $477-$

Table 4 Relative ratio of $\mathrm{Ca}$ and $\mathrm{P}$ of mandibular condyle by quantitative $\mathrm{X}-\mathrm{ray}$ microanalysis

\begin{tabular}{c|c|c|c|c}
\hline \hline & Control group & $\begin{array}{c}\text { Zn-deficient diet } \\
\text { group }\end{array}$ & $\begin{array}{c}\text { Low-Zn diet } \\
\text { group }\end{array}$ & $\begin{array}{c}\text { High-Zn diet } \\
\text { group }\end{array}$ \\
\hline $\mathrm{Ca} /[\mathrm{Ca}]_{\mathrm{c}}$ & 1.00 & 0.98 & 0.99 & 1.02 \\
\hline $\mathrm{P} /[\mathrm{P}]_{\mathrm{c}}$ & 1.00 & 1.04 & 1.01 & 0.98 \\
\hline
\end{tabular}

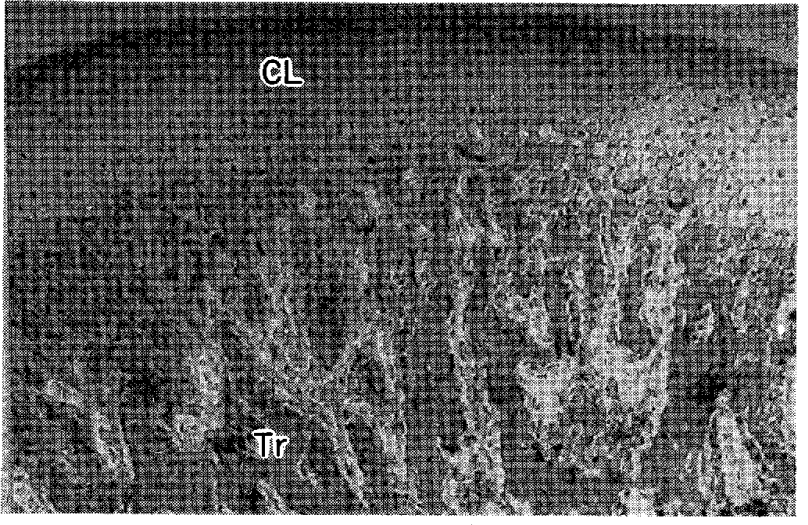

Fig. 1 Alveolar bone from the 9-week-old rat in the control group.

$\mathrm{H} \cdot \mathrm{E}$ stain $(\times 50)$

CL : Cartilage layer

Tr : Trabeculae

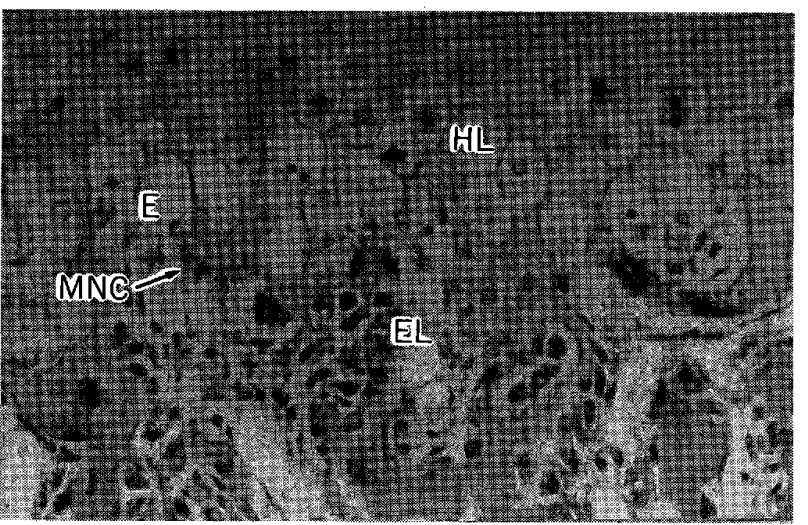

Fig. 3 A high magnification of Fig. 1. $\mathrm{H} \cdot \mathrm{E}$ stain $(\times 200)$

HL : Hypertrophic layer

EL : Erosive layer

MNC : Multinucliated cell (chondroclast)

E : Erosion

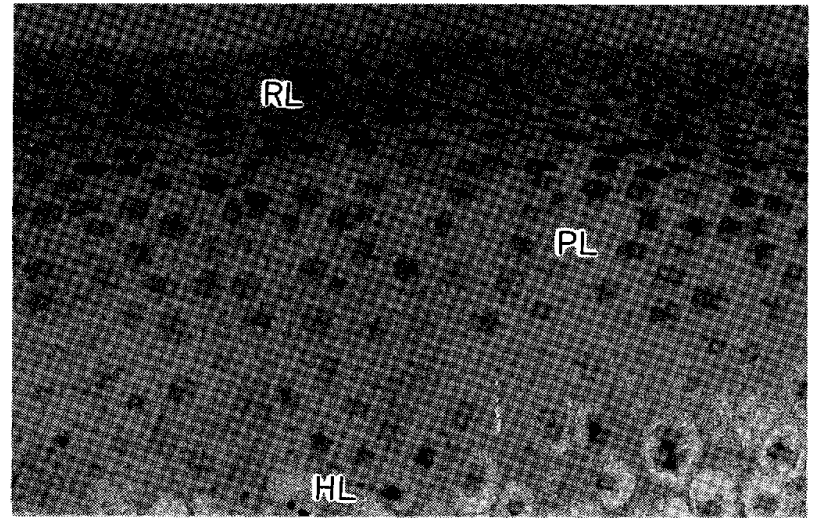

Fig. 2 A high magnification of Fig. 1.

$\mathrm{H} \cdot \mathrm{E}$ stain $(\times 200)$

RL : Resting layer

PL : Proliferative layer

HL : Hypertrophic layer

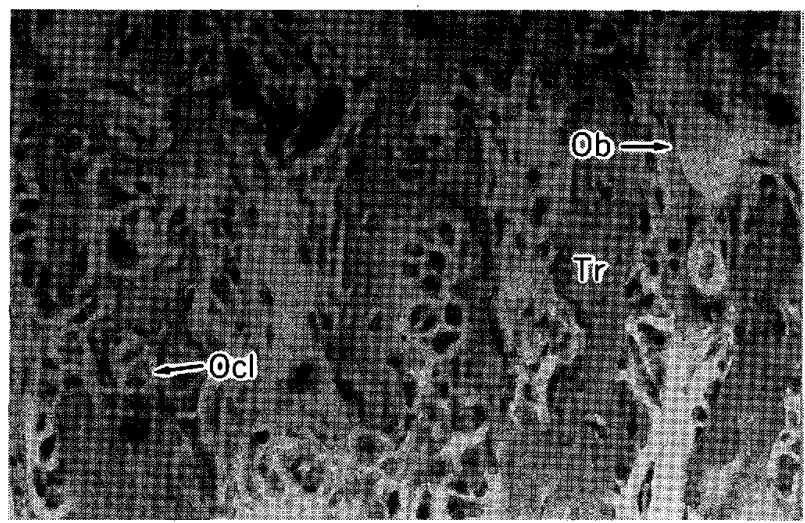

Fig. 4 A high magnification of Fig. 1.

$\mathrm{H} \cdot \mathrm{E}$ stain $(\times 200)$

Ob : Osteoblast

Ocl : Osteoclast

Tr : Trabeculae 


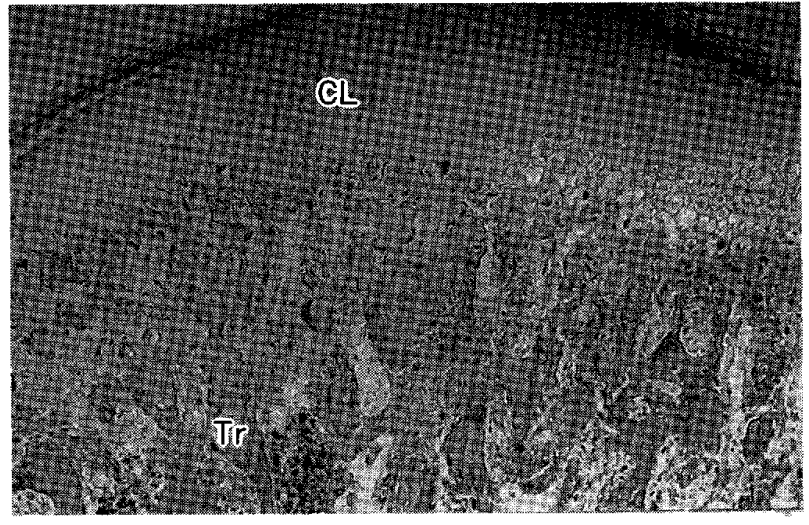

Fig. 5 Alveolar bone from the 9-week-old rat in the $\mathrm{Zn}$-deficient diet group.

$\mathrm{H} \cdot \mathrm{E}$ stain $(\times 50)$

CL : Cartilage layer

Tr : Trabeculae

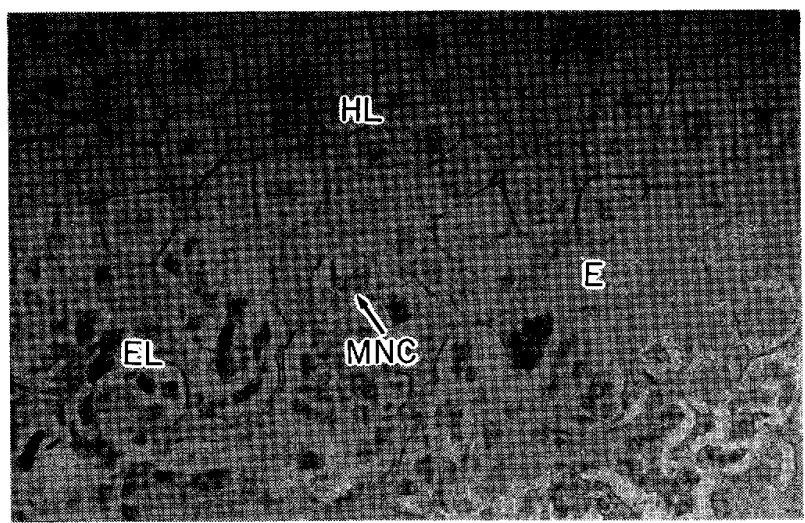

Fig. 7 A high magnification of Fig. 5.

$\mathrm{H} \cdot \mathrm{E}$ stain $(\times 200)$

HL : Hypertrophic layer

EL : Erosive layer

MNC: Multinucliated cell (chondroclast)

$\mathrm{E}$ : Erosion

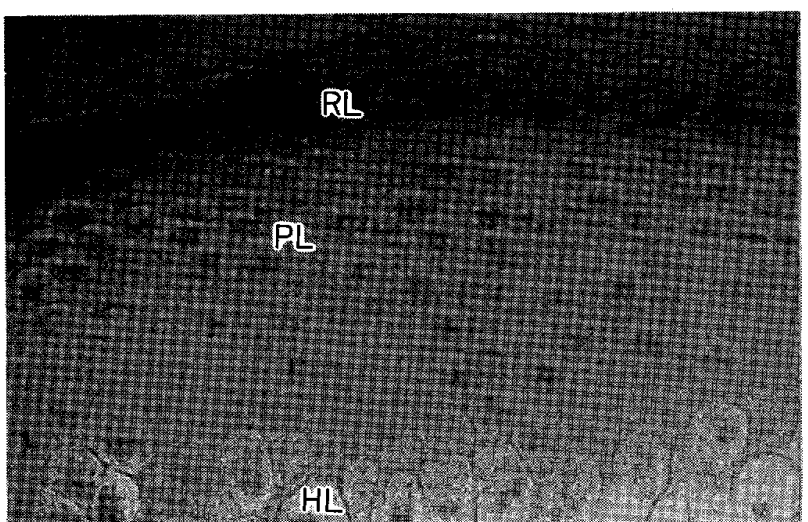

Fig. 6 A high magnification of Fig. 5 .

$\mathrm{H} \cdot \mathrm{E}$ stain $(\times 200)$

RL : Resting layer

PL : Proliferative layer

HL : Hypertrophic layer

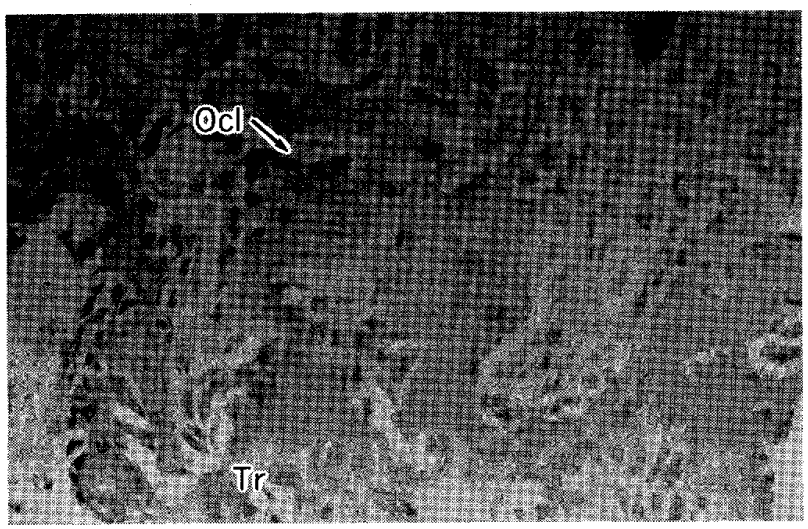

Fig. 8 A high magnification of Fig. 5 .

$\mathrm{H} \cdot \mathrm{E}$ stain $(\times 200)$

Ocl : Osteoclast

Tr : Trabeculae

the other three groups, and there is a significant difference between the high-zinc experimental group and the other three groups $(p<0.01)$. When compared with the control group, the high-zinc experimental group showed the higher relative $\mathrm{Ca}$ ratio and the lower $\mathrm{P}$ ratio, while the zinc-deficient experimental group and the low-zinc experimental group showed the lower relative $\mathrm{Ca}$ ratio and the higher $\mathrm{P}$ ratio. The relative ratios of $\mathrm{Ca}$ and $\mathrm{P}$ in all the groups are presented in Table 4.

\section{Histopathological findings}

I . Control group

The zonation of the condylar cartilage in the control group could be described as follows. 


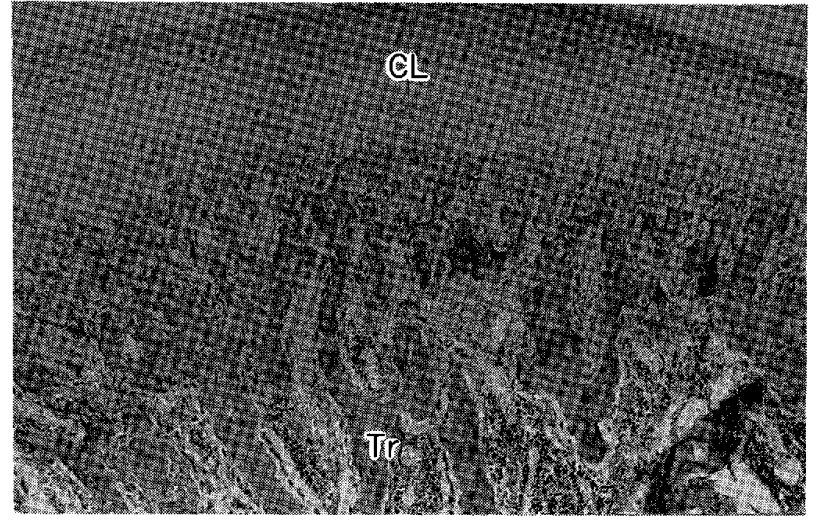

Fig. 9 Alveolar bone from the 9-week-old rat in the Low- $\mathrm{Zn}$ diet group.

$\mathrm{H} \cdot \mathrm{E}$ stain $(\times 50)$

$\mathrm{CL}$ : Cartilage layer

Tr : Trabeculae

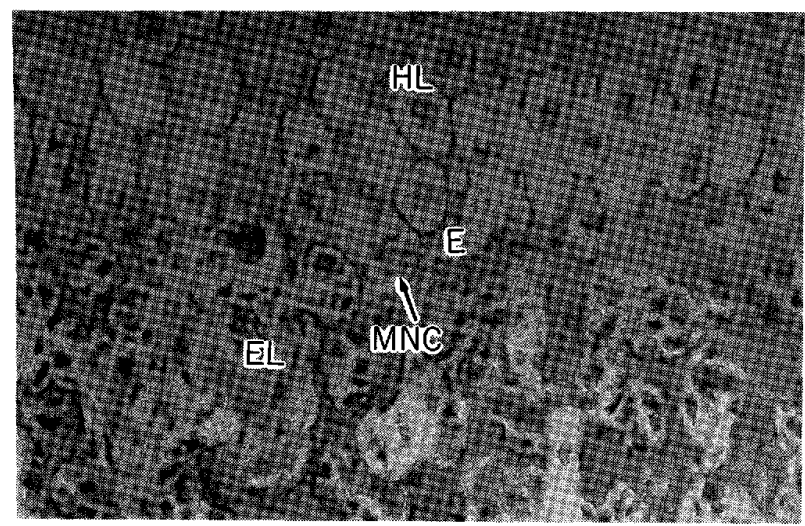

Fig. 11 A high magnification of Fig. 9.

$\mathrm{H} \cdot \mathrm{E}$ stain $(\times 200)$

HL : Hypertrophic layer

EL : Erosive layer

MNC: Multinucliated cell (chondroclast)

E : Erosion

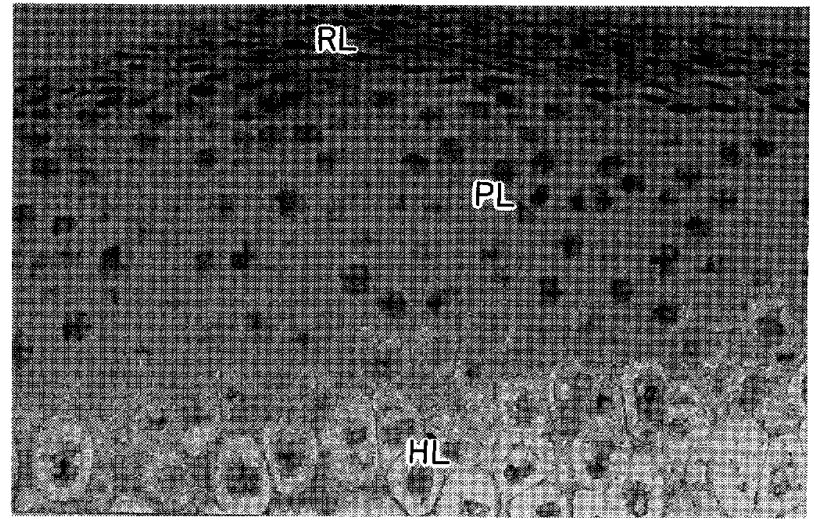

Fig. 10 A high magnification of Fig. 9.

$\mathrm{H} \cdot \mathrm{E}$ stain $(\times 200)$

RL : Resting layer

PL : Proliferative layer

HL : Hypertrophic layer

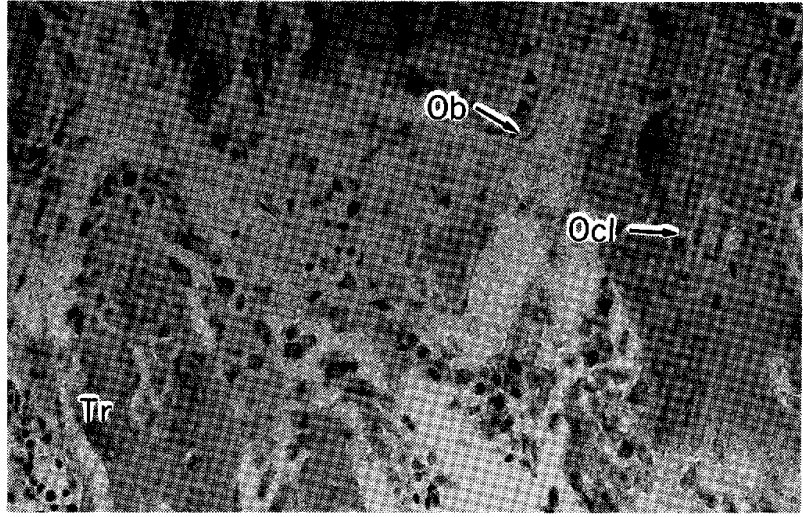

Fig. 12 A high magnification of Fig. 9.

$\mathrm{H} \cdot \mathrm{E}$ stain $(\times 200)$

$\mathrm{Ob}:$ Osteoblast

Ocl : Osteoclast

Tr : Trabeculae

On the superficial surface of the condyle was resting zone. The cartilage cells in this region appeared elongate and flat, whose long axes paralleled to the surface of condylar joint. Adjacent to this zone was zone of proliferation. The cartilage cells here underwent division and became organized into distinct columns. Next is zone of hypertrophy. The cartilage cells were greatly enlarged and appeared honeycombed, which were surrounded by a little calcified-matrix. In the next zone, many multinucleated chondroclasts invaded the calcifiedmatrix. Thus, it was referred as zone of erosion. And finally, zone of subchondral bone formation, which was in direct contact with the bone trabeculae, was represented by active bone formation. On the surface of bone trabeculae also appeared the active bone formation, where osteoblasts and osteoclasts could be seen (Fig. 1-4). 


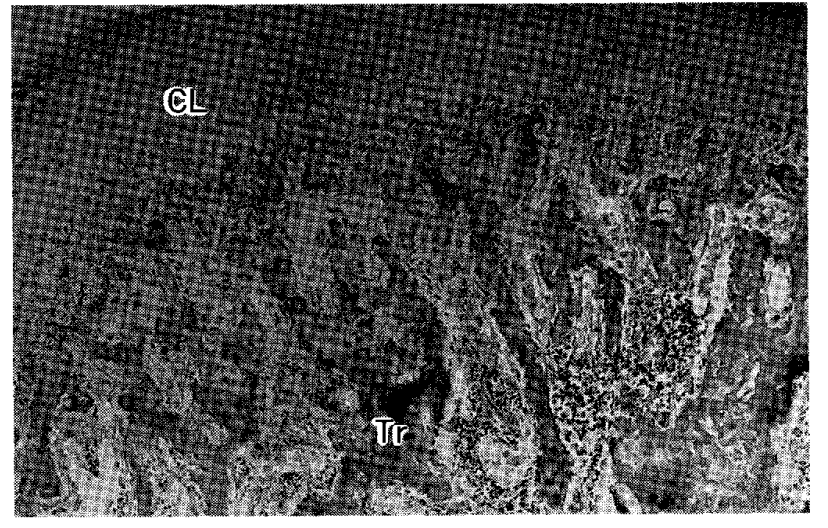

Fig. 13 Alveolar bone from the 9-week-old rat in the High $-\mathrm{Zn}$ diet group.

$\mathrm{H} \cdot \mathrm{E}$ stain $(\times 50)$

CL : Cartilage layer

$\operatorname{Tr}$ : Trabeculae

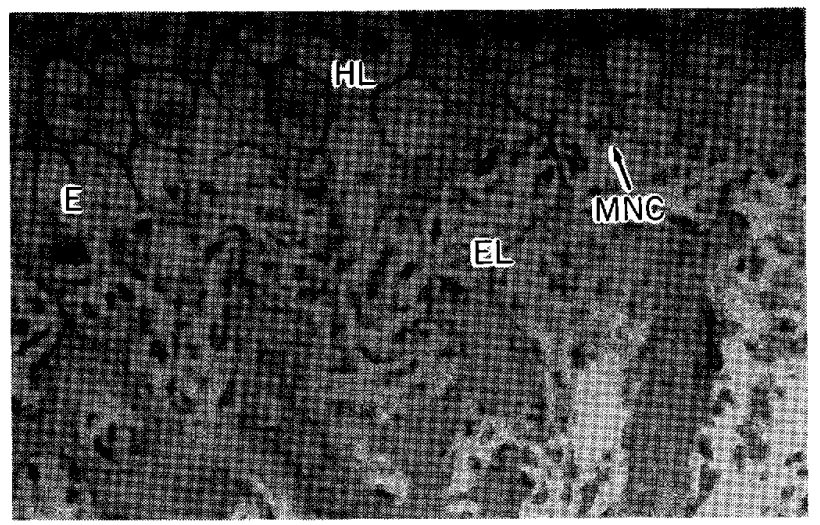

Fig. 15 A high magnification of Fig. 13.

$\mathrm{H} \cdot \mathrm{E}$ stain $(\times 200)$

HL : Hypertrophic layer

EL : Erosive layer

MNC: Multinucliated cell (chondroclast)

E : Erosion

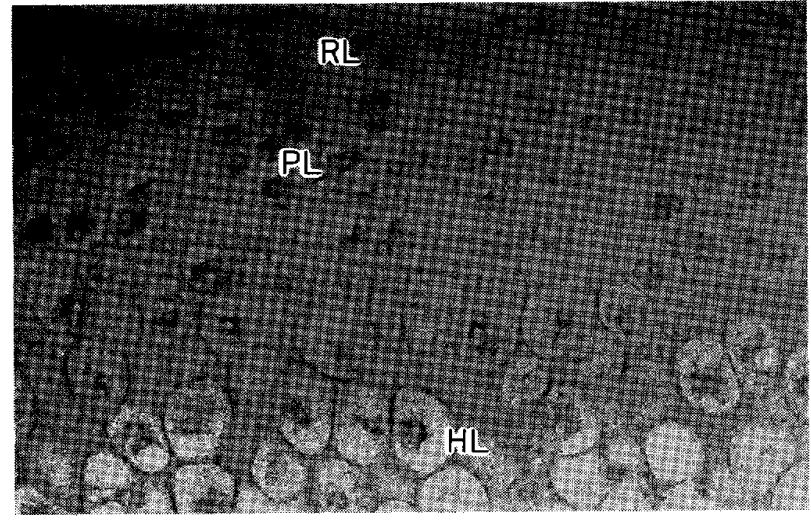

Fig. 14 A high magnification of Fig. 13.

$\mathrm{H} \cdot \mathrm{E}$ stain $(\times 200)$

RL : Resting layer

PL : Proliferative layer

HL : Hypertrophic layer

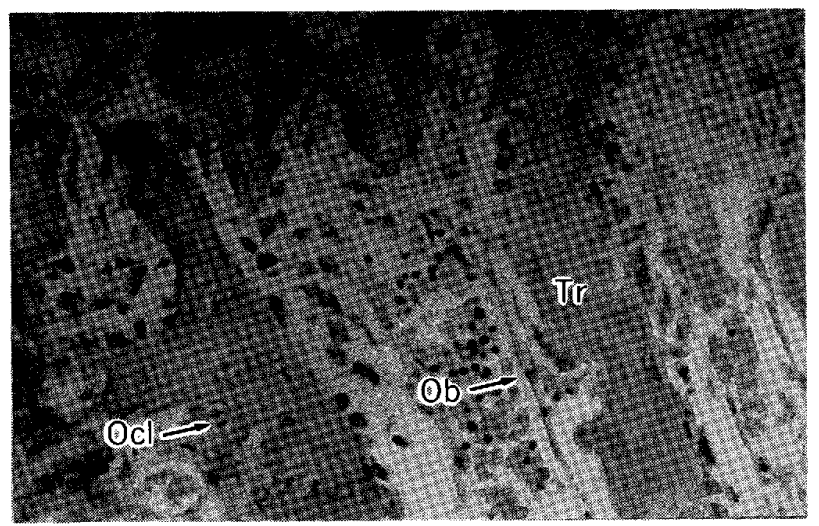

Fig. 16 A high magnification of Fig. 13.

$\mathrm{H} \cdot \mathrm{E}$ stain $(\times 200)$

$\mathrm{Ob}$ : Osteoblast

Ocl : Osteoclast

$\operatorname{Tr}$ : Trabecula

\section{Zinc-deficient experimental group}

Compared with the control group, the cartilage cells in resting zone tended to decrease, and their shapes and arrangements appeared irregular. The cartilage cells in zone of proliferation also had a tendency to decrease and their shapes were greatly enlarged and deformed. In zone of hypertrophy appeared the decreased calcified matrix, which were surrounded by the increased cartilage cells. The erosion of calcified matrix by the multinucleated chondroclasts tended to decrease. In zone of subchondral bone formation, the differentiation of chondrocytes into osteocytes was inhibited and the newly formed trabeculae seemed thin (Fig. 5-8). 


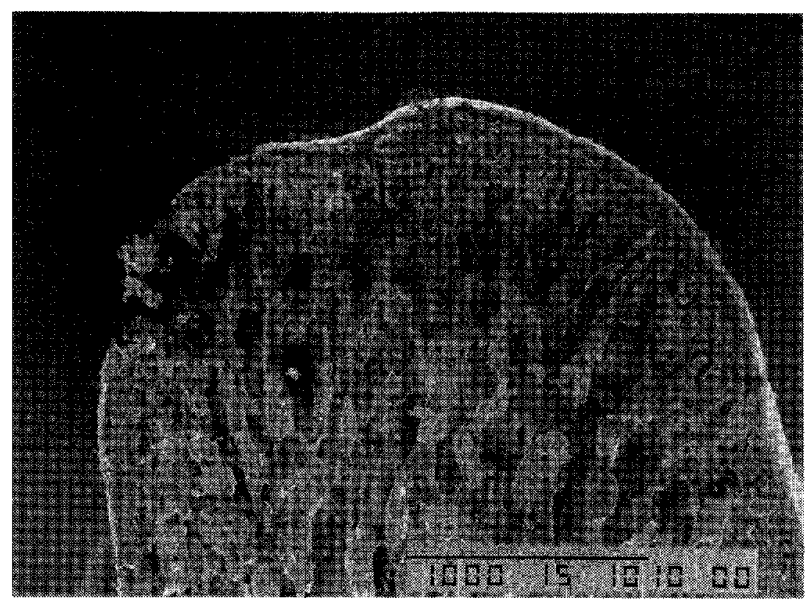

Fig. 17 9-week-old alveolar bone. (SEM) Control group

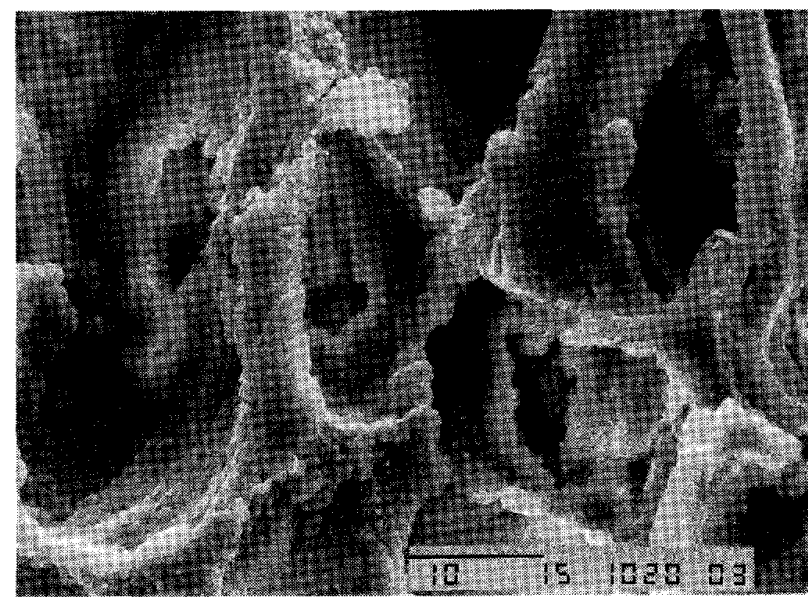

Fig. 18 A high magnification of Fig. 17. (SEM)

\section{Low-zinc experimental group}

Compared with the zinc-deficient experimental group, the number of the cartilage cells in resting zone was increased, part of them paralleling to the surface of condylar joint. The cartilage cells in zone of proliferation were increased and enlarged, appearing circular. The zone of hypertrophic cartilage cells was thinner and tended to increase. The calcified matrix around these cartilage cells also showed to be increasing. The bone trabeculae newly formed by increased subchondral bone formation seemed to be still thin (Fig. 9-12).

\section{High-zinc experimental group}

Compared with the control group, the cartilage cells in resting zone were decreased and in an irregular alignment. The cartilage cells in zone of proliferation appeared to be decreased, enlarged and irregularly arranged. The cartilage cells in zone of hypertrophy almost had no change in number, but it seemed clear that there was a tendency to increase the calcified matrix around these cartilage cells. The multinucleated chondroclasts here tended to increase, so that the erosion of calcified matrix was frequently observed and the differentiation of chondrocytes into osteocytes in zone of subchondral bone formation was promoted, leading to the successive and thick bone trabeculae with a vertical arrangement (Fig. 13-16).

\section{Scanning electron microscopic findings}

\section{Control group}

Upon the examination of an overall image of the condyle, on the cut face appeared the growing cartilage layer. At the lower end of the condyle, thick ossification occurred and many small marrow cavities could be clearly observed. A distinct division between the cartilage and the bone trabeculae could be seen (Fig.17). On the upper surface of cartilage lacunae appeared the calcifying longitudinal matrix. Cartilage lacunae were full of small calcareous globes with the size of around $0.5 \mu \mathrm{m}$. On the longitudinal matrix, collagen fibers 


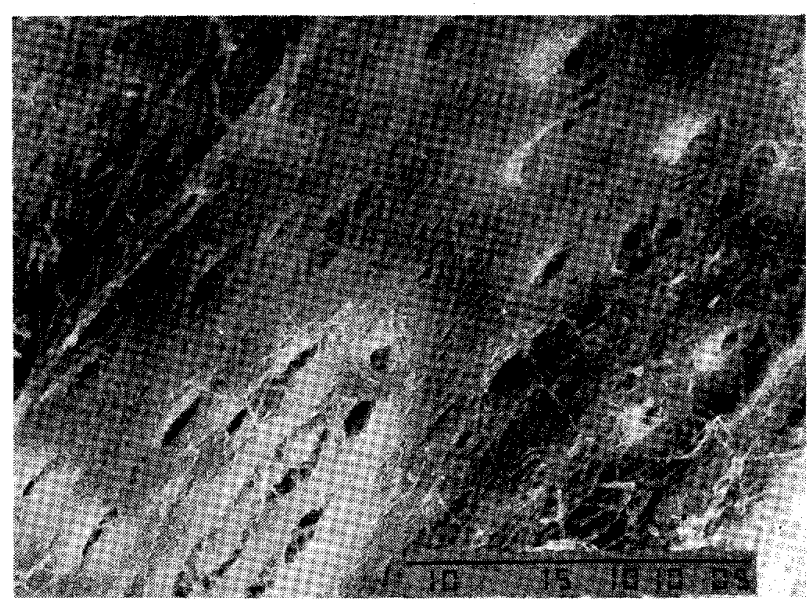

Fig. 19 A high magnification of Fig. 17. (SEM)

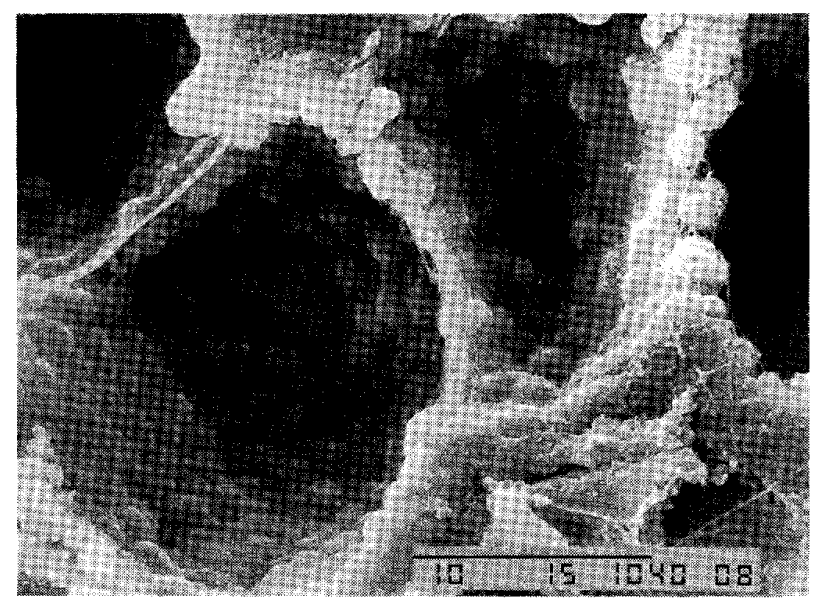

Fig. 21 A high magnification of Fig. 20. (SEM)

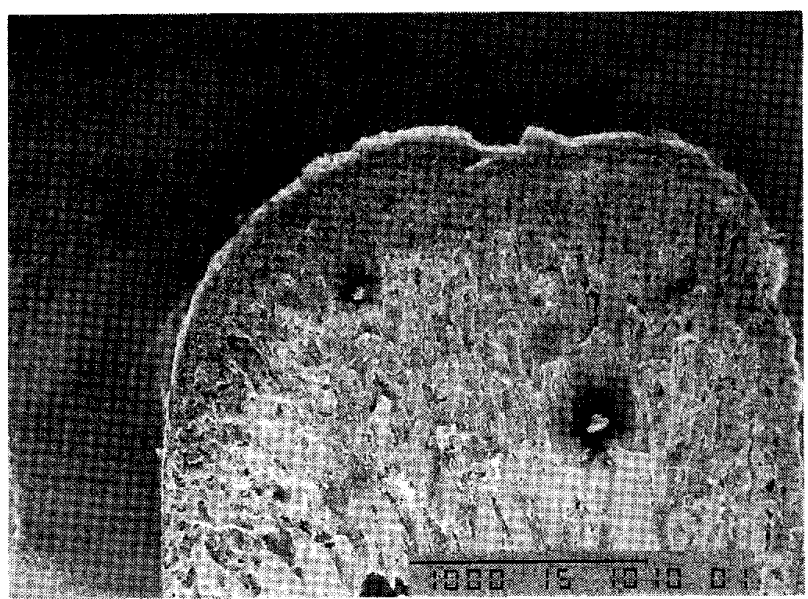

Fig. 20 9-week-old alveolar bone. (SEM) Zn-deficient diet group

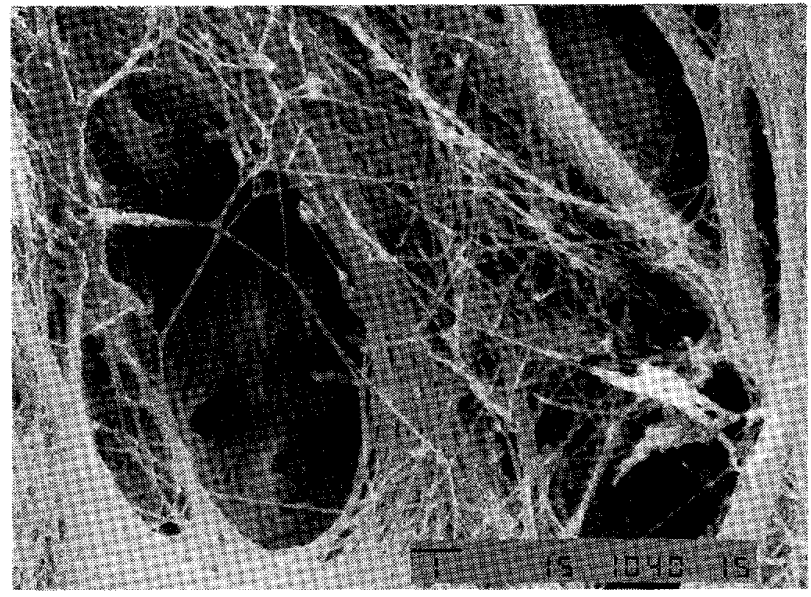

Fig. 22 A high magnification of Fig. 20. (SEM)

were seen crossed into networks. But occasionally part of the longitudinal matrix, on which successive collagen fibers formed, was occupied by only a few calcareous globules (Fig. 18).

In the formation areas of bone matrix appeared the surface of bone formation, which was adjacent to the surface of bone resorption. On the surface of bone formation showed many dense collagen bundles in a particular alignment. There were many bone lacunae, on the wall of which collagen fibers were clearly seen crossed into networks. On the surface of collagen fibers appeared some micro- calcareous depositions (Fig. 19).

II. Zinc-deficient experimental group

Same as the control group, there was a distinct division between the cartilage layer and the following bone trabeculae, newly formed by endochondral ossification. But the bone trabeculae appeared thinner than those in the control group (Fig. 20).

Compared with the control group, there was a distinct division among the cartilage lacunae, on the wall of which sparse calcareous globules and collective collagen fibers were 


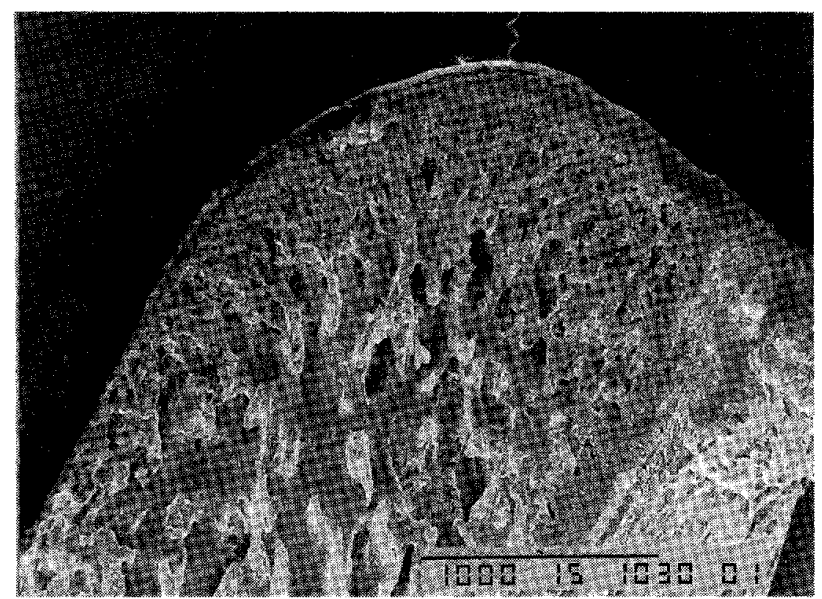

Fig. 23 9-week-old alveolar bone. (SEM) Low-Zn diet group

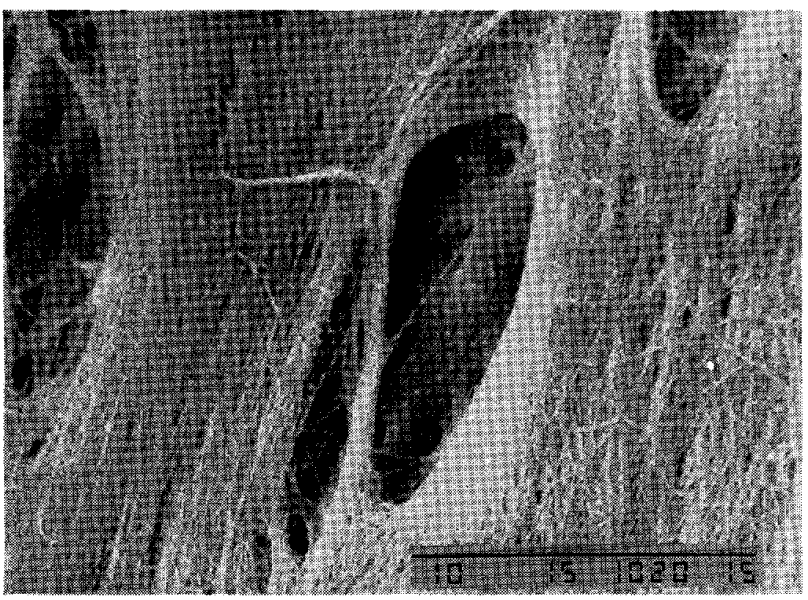

Fig. 25 A high magnification of Fig. 23. (SEM)

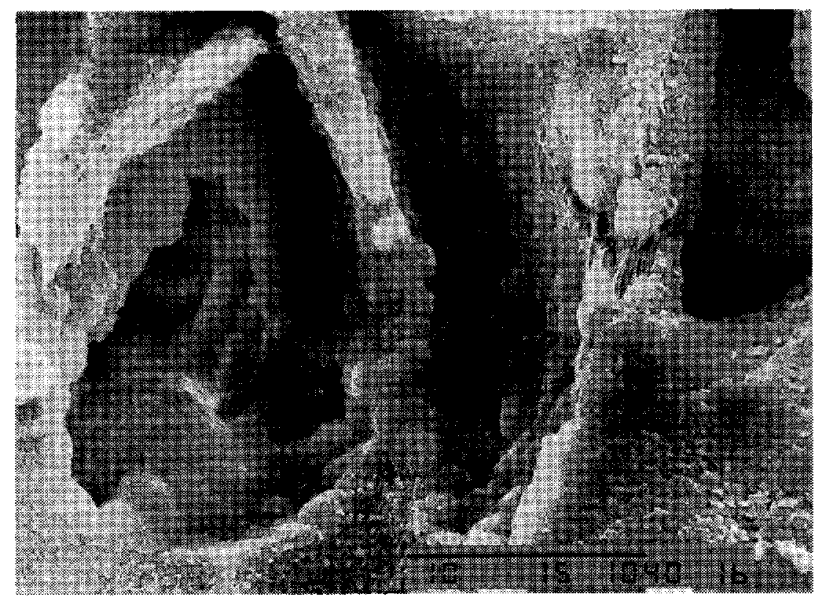

Fig. 24 A high magnification of Fig. 23. (SEM)

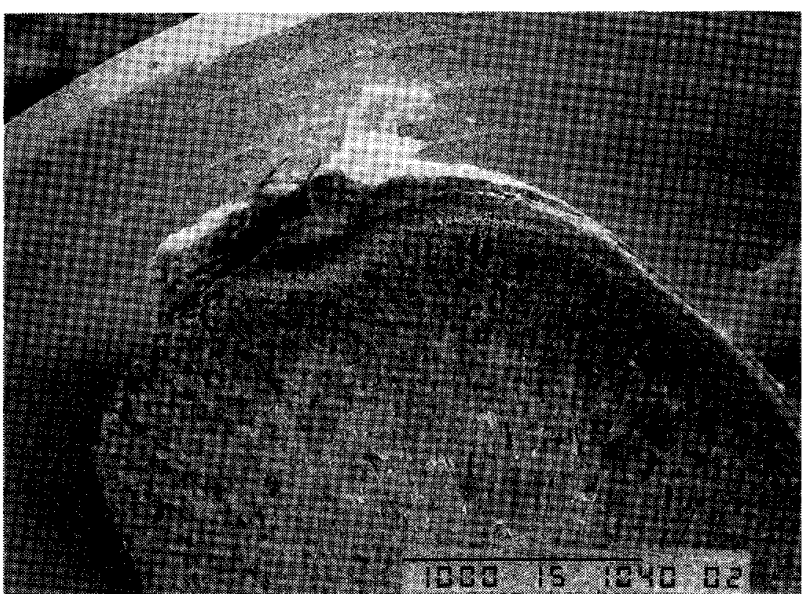

Fig. 26 9-week-old alveolar bone. (SEM) High-Zn diet group

frequently seen, and the smooth surfaces of longitudinal matrix tended to decrease (Fig. 21).

On the surface of bone formation, the wide-spread bone resorption areas were present, causing bone lacunae and canalicali to expose. The sites with an unclear division between bone lacunae and osteocytic matrix were readily observed, where collagen fibers crossed into networks. On the formation surface of bone matrix, collagen fiber bundles arranged sparsely, thus leading to many incompletely formed bone lacunae, which had an unclear division with bone matrix. On the surface of collagen fibers with an irregular alignment appeared some micronized calcareous depositions (Fig. 22).

III. Low-zinc experimental group

Upon the examination of an overall image of a cut surface, when compared to the zincdeficient experimental group, ossification was seen increased, thus the thick bone trabeculae came to form (Fig. 23).

The findings of cartilage lacunae were the same as those in the zinc-deficient experimental 


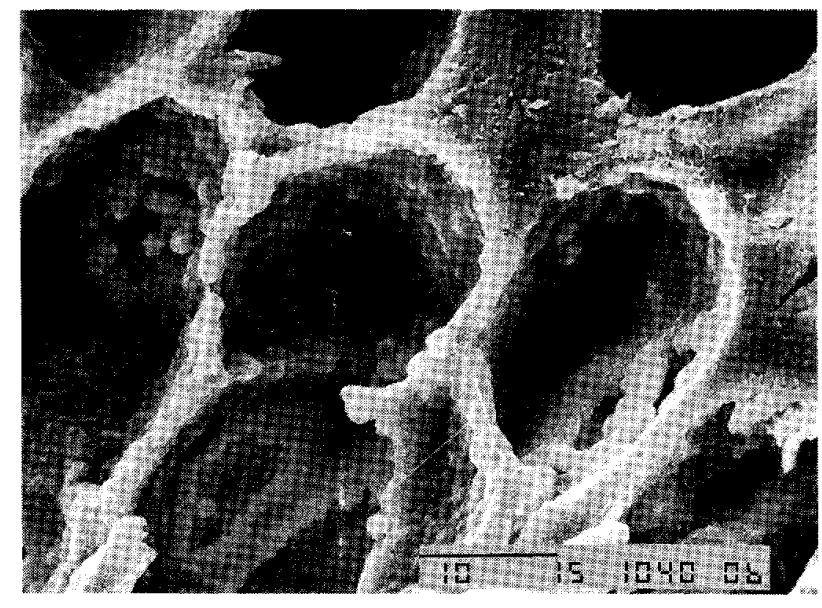

Fig. 27 A high magnification of Fig. 26. (SEM)

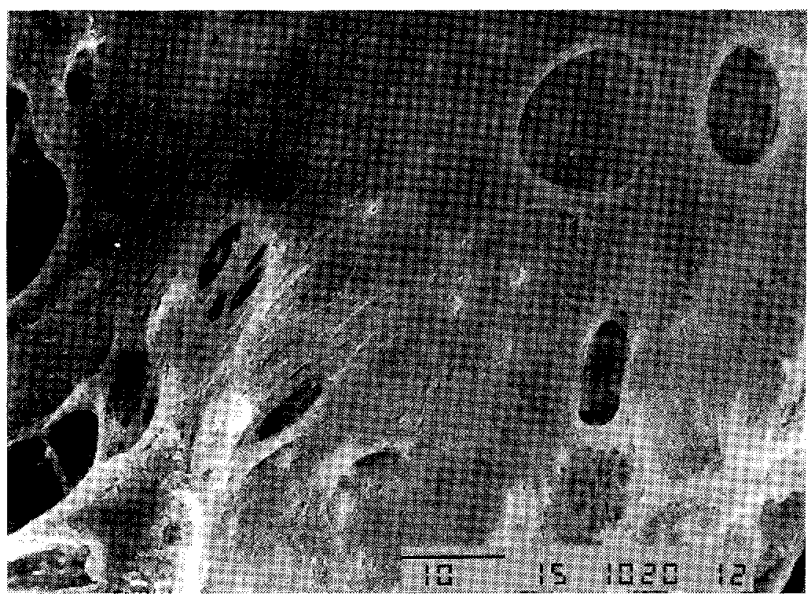

Fig. 28 A high magnification of Fig. 26. (SEM)

group, that there was a clear division among the cartilage lacunae. On the wall of cartilage lacunae arranged a few calcareous globules, where collagen fibers were readily seen connected (Fig. 24).

Compared to the zinc-deficient experimental group, on bone formation surface appeared many collagen fiber bundles in a particular alignment, and the sites with a distinct division between the bone lacunae and bone matrix were frequently observed. Same as the control group, on the superficial layer, collagen fibers were obviously seen crossed into networks. Bone canaliculi were observed among the crossed and dense collagen fibers in the bone lacunae (Fig. 25).

IV. High-zinc experimental group

Upon the examination of an overall image of a cut surface, when compared with the control group, the cartilage development from the growing cartilage layer to the following thick bone trabeculae was improved (Fig. 26).

The findings of cartilage lacunae were nearly the same as those in the control group, showing there was a distinct division among the cartilage lacunae and longitudinal matrix could also be observed (Fig. 27).

Bone formation surfaces, on part of which still appeared incomplete bone lacunae, seemed smooth, showing the same findings as those in the control group (Fig. 28).

\section{Discussions}

It is determined that sufficient calcium intake has a positive effect on bone formation. Recently, improving calcium absorption becomes so important that we have reported a series of studies ${ }^{2-10)}$ on clarifying the relationships between calcium and some nutrients such as protein and magnesium, and some physiological active factors such as 1,25-dihydroxyvitamin $\mathrm{D}_{3}$ and calcitonin, and physical activity. Furthermore, zinc, an essential trace element, has lately attracted considerable attention. Many investigators described a zinc-deficient syndrome ${ }^{11-14)}$ clinically characterized by growth retardation or stop, loss of appetite, dermal 
lesions, hypogonadism, and remarkable bone diseases. It also has been reported that zinc deficiency in rats during the early growing period produced the sudden stop of growth and development $t^{15)}$. Zinc deficiency caused a decrease of alkaline phosphatase activity, leading to incomplete bone formation ${ }^{16,17)}$. Hozaki et al. (1995) ${ }^{18)}$ reported that zinc deficiency could result in a disorder of the growth and development, and the initial calcification of condylar cartilage matrix in the rats given zinc-deficient diet. Nishida et al. ${ }^{19)}$ examined the effects of zinc and active vitamin $D_{3}$ on bone formation by endochondral ossification in rat condylar cartilage, and reported that zinc deficiency could cause a decline in bone modeling and zinc supplementation could enhance the effect of active vitamin $D_{3}$ on bone formation. However, Abe $(1995)^{20)}$ reported that zinc had no effect on bone metabolism, especially bone formation, so that it was difficult to determine that zinc compounds could enhance bone formation in growing rats. By now, the mechanism by which zinc affects bone formation is unknown.

In this study, to determine the effect of zinc on bone formation at growth stage, we fed the rats on food with different zinc levels and then examine their condyles.

\section{Densitometric measurement}

This is one of approaches to objectively evaluate the degree of bone modeling. In this investigation, when $\mathrm{X}$-ray photographs were taken, softex CSM and Al step wedges were used, causing the conversion of bone density into Al equivalent. The control group, low-zinc experimental group and high-zinc experimental group showed the same value of $1.00 \mathrm{~mm}$, while the zinc-deficient experimental group showing the low value of $0.50 \mathrm{~mm}$. There was a significant difference between the control group and the zinc-deficient group $(p<0.01)$, and the latter showed the low value.

Bone remodeling was influenced by zinc deficiency, but not by low-zinc or high-zinc condition. It is possible that insufficient zinc intake in some degree could have no effect on bone density, since zinc level in vivo may be regulated by a homeostasis-supporting system. Nishida $(1995)^{19)}$ pointed out that there was no significant difference between the control group and the low-zinc diet and active vitamin $\mathrm{D}_{3}$ experimental group. Abe (1995) ${ }^{20)}$ reported that excessive zinc intake had no effect on bone formation or bone metabolism.

\section{Microanalysis for $\mathrm{Ca}$ and $P$}

Fujimoto et al. $(1980)^{21)},(1981)^{22)}$ did the microanalysis for $\mathrm{Ca}$ and $\mathrm{P}$ of condylar cartilage in growing rats and then reported that the levels of $\mathrm{Ca}$ and $\mathrm{P}$ could reach the peak remarkably with the improvement of calcification.

In the present study, there was no significant difference between the control group and the low-zinc experimental group. There was a significant difference $(p<0.01)$ between the zincdeficient experimental group and the other three groups, and the zinc-deficient experimental group showed the lower value of the relative Ca ratio. There was also a significant difference $(\mathrm{p}<0.01)$ between the high-zinc experimental group and the other three groups, and the high-zinc experimental group showed the higher value of the relative $\mathrm{Ca}$ ratio. 
Therefore, it is suggested that bone modeling may be inhibited by zinc deficiency and enhanced by zinc supplementation.

\section{Histopathological findings}

It has been known that the condyle develops by endochondral ossification with the skeletal growth. It was the characteristic of the 5-day-old condyle ${ }^{23)}$ that the cartilage layer on the superficial surface remains indefinitely because of no appearance of the second ossification center, in spite that the same calcification as that in the other long bones could be observed. In the 3-week-old condyle, the cartilage layer was clearly differentiated and the cartilage cells were actively proliferating. In the 6-week-old condyle, the width of the cartilage layer was decreased, and the active trabecular formation occurred, nearly in condition of maturity ${ }^{24)}$. In the 7 -week-old condyle ${ }^{25}$, the cartilage layer became very thin with the decrease of the cartilage cells in zones of proliferation and hypertrophy; calcified matrix around zone of hypertrophy was increased; the erosion of calcified matrix by chondroclasts and bone formation under cartilage could be observed. In the 9 -week-old condyle ${ }^{26}$, the width of cartilage layer was decreased and changing over to calcification ${ }^{26}$. It was reported ${ }^{27)}$ that the cartilage layer of the rat condyle tended to decrease by aging, showing the same findings as under the condition of malnutrition. Hozaki et al. $(1995)^{18)}$ reported that the cartilage cells of the condyle in zinc deficient experimental rats were decreased when compared with the control group, and especially the cartilage cells in zone of hypertrophy, suggesting that the formation of new cartilage cells was inhibited. Nakao $(1987)^{25)}$ reported that in the condyle of the growing rats given calcium-deficient diet, the cartilage layer was increased, resulting from the increased cartilage cells in zone of hypertrophy. The decrease of the calcified matrix around cartilage cells of hypertrophic zone and the chondroclasts in zone of erosion could be seen, and the trabeculae became slender and sparse.

In this study, compared with the control group, the zinc deficient experimental group showed the decreased cartilage cells in resting zone and zone of proliferation, same as the findings reported by Hozaki, suggesting that the formation of new cartilage cells may be inhibited. The cartilage cells in zone of hypertrophy were increased, accompanied by the decrease of chondroclasts; calcified matrix surrounding the cartilage cells was decreased; bone formation in zone of subchondral bone formation was inhibited, showing the same findings as in condition of calcium deficiency. Zinc deficiency had a bad effect on calcium metabolism, such as the low metabolic rotation and few stores of calcium when compared with the normal zinc level ${ }^{28}$. Compared with the zinc deficient diet group, the low zinc diet group showed the increased cartilage cells in resting zone and zone of proliferation, and the decreased cartilage cells in zone of hypertrophy resulted from the increase of chondroclasts. All the changes were thought to result from the different zinc intake.

Zinc deficiency has an effect not only on growth and development of cartilage cells but also on calcification of cartilage matrix. Hozaki et al. (1995) ${ }^{18)}$ reported that zinc deficiency could inhibit the carbonate dehydratase activity, which was considered to play an important 
role in the initial calcification, leading to the decrease of initial calcification of cartilage matrix. Nishida $(1995){ }^{19}$ indicated that the decrease of the calcified matrix around the cartilage was seen in the low zinc diet and active vitamin $D_{3}$ group, while the obvious increase appeared in the high zinc diet and active vitamin $\mathrm{D}_{3}$ group. In the present study, the zinc deficient experimental group showed not only the decrease of calcified matrix but also the thinner trabeculae in zone of subchondral bone formation. The low zinc experimental group showed the increase of calcified matrix and the improvement of subchondral bone formation when compared with the zinc deficient experimental group, not reaching the level of bone remodeling in the control group. The high zinc experimental group showed the increase of erosion by the increased chondroclasts, the improvement of subchondral bone formation, and the thick trabeculae when compared the control group.

As above, zinc deficiency not only inhibits the development of new cartilage cells, but also has an effect on calcium metabolism. Furthermore, bone formation or bone metabolism is inhibited because of the influenced calcium metabolism. On the other hand, zinc supplements increase the calcification and improve the differentiation of cartilage cells into bone cells, enhancing bone remodeling.

\section{Scanning electron microscopic findings}

Fujimoto (1982) ${ }^{29)}$ observed the cartilage cells in the condyle through scanning electron microscopy and described the findings as follows. The upper part of zone of hypertrophy showed the formation of the longitudinal matrix by the dense collagen fibers, on which globe-shaped structures were present. In the central part of zone of hypertrophy, the formation of calcified matrix appeared on the superficial surface of longitudinal matrix, inside which the dense collagen fibers crossed into a network. In this area, globe-shaped structures that were present during the formation of calcareous globules also could be seen. In the lower part of zone of hypertrophy, the longitudinal matrix was calcifying and on the wall of lacunae many calcareous globules were seen. On the surface of this area, dense collagen fibers crossed into a network, while inside of this area appeared calcification. Calcifying calcareous globules were seen to connect one another from the superficial surface to the area adjacent to layer of ossification. Calcareous globules are made from hydroxyapatite crystals according to the ratio of $\mathrm{Ca}$ to $\mathrm{P}$ by $\mathrm{X}$-ray analysis ${ }^{21}$, thought to be associated with the initial calcification by endochondral ossification ${ }^{30)}$. Suzuki et al. $(1979)^{31)}$ examined the globe-shaped structures on the wall of bone lacunae by scanning electron microscopy, and found the structures connecting one another at all the stages of bone matrix formation, suggesting that calcification was the mature stage of matrix formation. Shioda et al. $(1980)^{32)}$ did the ultrastructural observation by scanning electron microscopy and found that the diameter of the cartilage lacunae was different at the different sites. In the rats at the early growth spurt appeared the abundant cartilage lacunae with small diameter, the number of which was decreased by aging and the shape became irregular. Taniguchi $(1981)^{33}$ reported that in the trabeculae, the big and elliptical bone lacunae with the ability to form bone matrix could be 
seen when the bone matrix was formed by the active osteoblasts.

Zinc supplements could improve the cartilage calcification, showing that the matrix was formed with the connection of calcareous globules one another, the cartilage layer was distinctly divided, and the calcification of collagen fibers on the bottom of cartilage lacunae was frequently observed. On the other hand, zinc deficiency could inhibit the cartilage calcification, showing that there was no distinct division among the cartilage lacunae, on the bottom of which deposited irregular calcareous globules, and the cartilage matrix formation at the stage of initial calcification ${ }^{19}$. The present study showed the same findings. When compared with the control group, the zinc deficient experimental group showed the decreased calcification of longitudinal matrix and cartilage lacunar wall, the widespread bone resorption in zone of subchondral bone formation, the irregular and sparse arrangement of collagen fibers on the surface of bone formation, and the calcareous microdepositions present on the surface of the collagen fibers around bone lacunae. When compared with zinc deficient experimental group, the low zinc experimental group showed that ossification was improved and the thick trabeculae were formed, suggesting that zinc had a key effect on bone remodeling, especially on the calcification in cartilage layer and the ossification in zone of subchondral bone formation. Furthermore, zinc supplements could improve the development of the cartilage from the ossification of the growing cartilage layer to the following thick trabeculae, suggesting that zinc had an effect on the growth and development of the condylar cartilage.

The present study suggested that zinc, an essential element, had a positive effect on bone formation by endochondral ossification in the condyles of the growing rats.

\section{Conclusions}

In this study, we used 5-week-old Wistar male rats, corresponding to childhood in humans, to examine the effects of zinc on bone formation by endochondral ossification at growth stage.

1. Densitometric measurement

There was a significant difference between the zinc deficient experimental group and the other three groups $(\mathrm{p}<0.01)$, and the zinc deficient experimental group showed the low value.

2. Microanalysis for $\mathrm{Ca}$ and $\mathrm{P}$

There was no significant difference in the content of Ca between the low-zinc experimental group and the control group. The zinc-deficient experimental group showed the lower content of $\mathrm{Ca}$ than the other three groups, and there was a significant difference between the zinc-deficient experimental group and the other three groups $(p<0.01)$. The high-zinc experimental group showed the higher content of $\mathrm{Ca}$ than the other three groups, and there is a significant difference between the high-zinc experimental group and the other three groups $(\mathrm{p}<0.01)$. When compared with the control group, the high-zinc experimental group showed the higher relative $\mathrm{Ca}$ ratio and the lower $\mathrm{P}$ ratio, while the zinc-deficient 
experimental group and the low-zinc experimental group showed the lower relative Ca ratio and the higher $\mathrm{P}$ ratio.

3. Histopathological findings

Compared with the control group, the zinc deficient experimental group showed the decreased cartilage cells in resting zone and zone of proliferation with the deformed shape. In zone of hypertrophy appeared the decreased calcified matrix, which were surrounded by the increased cartilage cells. The erosion of calcified matrix by the multinuclear chondroclasts tended to decrease. In zone of subchondral bone formation appeared the thinner trabeculae.

Compared with the zinc-deficient experimental group, the low zinc experimental group showed the increase of the cartilage cells in resting layer and in layer of proliferation and the decrease in zone of hypertrophy. The increased erosion findings of the calcified matrix, surrounded by the increased hypertrophic cartilage cells, could be observed frequently. The subchondral bone formation was improved, but the trabeculae were thinner.

Compared with the control group, the high zinc experimental group showed the decrease of the cartilage cells in resting zone and zone of proliferation, with the irregular arrangement. The increase of both the calcified matrix surrounded by the hypertrophic cartilage cells and the erosion of the calcified matrix by the increased chondroclasts could be often seen. In zone of bone formation under cartilage the differentiation of cartilage cells into bone cells was improved, leading to the successive and thick bone trabeculae in a verticle arrangement.

4. Scanning electron microscopic findings

Compared with the control group, the zinc deficient experimental group showed the thinner bone trabeculae and the decrease of the longitudinal matrix in cartilage lacunae, on the wall of which appeared the calcareous globules in a sparse arrangement and the collective collagen fibers. In zone of subchondral bone formation the bone resorption areas widely spread. The sites with an unclear division between bone lacunae and bone matrix were readily observed, where collagen fibers crossed into networks. On the surface of bone matrix formation, collagen fibers arranged sparsely and were in an irregular alignment, where the calcareous microdepositions were present.

Compared with the zinc deficient experimental group, the low zinc experimental group showed the thick trabeculae. In the cartilage lacunae arranged the uncalcified globes, where the collagen fibers were often seen crossed into networks. On the bone formation surface appeared many collagen fiber bundles in a regular alignment, and on the superficial part the collagen fibers were clearly seen crossed into networks, showing the same as the findings in the control group.

Upon the examination of an overall image in the high zinc experimental group, compared with the control group, the cartilage development from the growing cartilage layer to the following thick bone trabeculae was improved. The findings of cartilage lacunae and bone formation surface were nearly the same as those in the control group.

The present study suggested that zinc, an essential element, had a positive effect on bone 
formation by endochondral ossification in the condyles of the growing rats.

\section{Acknowledgments}

The authors greatly thank the director, Professor Mitsutaka Kimura, and the staff of the Department of Pediatric Dentistry, Kyushu Dental College, for their help during this investigation.

\section{References}

1) Kyono, Y., Tanaka, H., Nishiyama, S. and Hiroda, T.: Factors related to peak bone mass. The Bone 8: 16-34, 1994.

2) Chen, I. K.: An experimental study on the mandible at growth stage and calcium intake. Change in the mandibular condyle in particular. J. Kyushu Dent. Soc. 43: 710-745, 1989.

3) Okura, H.: An experimental study on the effect of vitamin D on the mandibular condyle at growth stage. J. Kyushu Dent. Soc. 44 : 1-38, 1990.

4) Ryu, S.: A radiological and histopathological study on calcium intake and the mandible at maturation stage. Especially change in the mandibular condyle. J. Kyushu Dent. Soc. 45: 353-376, 1991.

5) Fukushima, N.: An electronic microscope study of formation of bone matrix in the mandibular condyle at growth stage -Effect of high protein-. J. Kyushu Dent. Soc. 47: 75-98, 1993.

6) Takahashi, H.: An experimental study on the effect of high protein on formation of bone in the mandible at growth stage. Formation of bone matrix. J. Kyushu Dent. Soc. 47: 459-479, 1993.

7 ) Yokomoto, M.: An experimental study on the combined treatment method of calcitonin and active vitamin $\mathrm{D}_{3}$ for debilitated mandible. J. Kyushu Dent. Soc. 47:533-551, 1993.

8) Morimoto, H.: The effect of physical exercise on the metaphysis of tibia in rats at the growth stage. An electron microscope study. J. Kyushu Dent. Soc. 48: 687-715, 1994.

9) Imamura, T.: Effects of physical exercise on the jaw bones of the rat at the growing and development stage. J. Kyushu Dent. Soc. 49: 495-527, 1995.

10) Saeki, K.: Effect of high protein on calcium absorption in the mandibular condyle of the rat at growth stage. Electron microscope investigation. J. Kyushu Dent. Soc. 50: 119-140, 1996.

11) Japanese Nutrition-Food Academy: Metallic element in living body. Koseikan Publishing Co., Tokyo, 1994, 1-11, 97-121.

12) Suzuki, T. and Wada, K.: Nutriology of mineral. Trace element. First Publishing Co., Tokyo, 1994, 377-395.

13) Hambidge, K. M., Hambidge, C., Jacobs, M. and Baum, J. D.: Low levels of zinc in hair, anorexia, poor growth, and hypogensia in children. Pediatr. Res. 6: 868-874, 1972.

14) Liyas, A., Funaba, M., Ashida, K., Yano, H. and Kawashima, R.: Effects of zinc deficiency on bone physical properties and trace minerals content in rats. Biomed. Res. Trace Elements $3: 103-104,1992$.

15) Williams, R. B. and Mills, C. F.: The experimental production of zinc deficiency in the rat. Brit. J. Nutr. $24: 989-1003,1970$.

16) Ronaghy, H. A., Reinhold, J. G., Mahloudji, M., Ghavami, P., Fox, M. R. S. and Halsted, J. A.: Zinc supplementation of malnourished school boys in Iran increased growth and other effects. Am. J. Nutr. 27 : 112-121, 1974.

17) Westmoreland, N.: Connective tissue alterations in zinc deficient rats. Fed. Proc. 30: 1001-1010, 1971.

18) Hozaki, T. and Takeyama, H. : Effect of dietary zinc deficiency on condylar cartilage growth, initial mineralization and experimental tooth movement in rat. J. Jpn. Orthod. Soc. 54:234-245, 1995.

19) Nishida, I. : Effect of zinc on growth and development of rat's condylar cartilage. Combined with 
activated vitamin $D_{3}$. J. Kyushu Dent. Soc. 52: 585-602, 1998.

20) Abe, K.: Studies on the effects of zinc compounds on the bone growth in rats. II. Effect of the zinc compound on bone metabolism in weanling rats. Acta Sch. Med. Univ. Gifu 43: 299-305, 1995.

21) Fujimoto, M., Taniuchi, Y. and Takiuchi, R.: Energy dispersive $\mathrm{X}$-ray analysis on cartilage of the mandibular condyle. J. Jpn. Oral Biol. 22 : 412-417, 1980.

22) Fujimoto, M., Goto, K. and Takiuchi, R.: Energy dispersive X-ray analysis and scanning electron microscopic observation on cartilage of the mandibular condyle. Acta Anat. Nippon 56: 72-78, 1981.

23) Miki, T.: Studies on the morphogenesis and age changes of the temporo-mandibular joint of normal rat. Bull. Stom. Kyoto Univ. 12:1-33, 1972.

24) Ohkoshi, K., Shimizu, W., Deguchi, M. and Oka, T: Histochemical studies on the temporomandibular joint of growing rat. J. oral Science 20:393-397, 1971.

25) Nakao, T.: A study on experimental osteoporosis of the mandible at growing stage. Especially on change in mandibular condyle. J. Kyushu Dent. Soc. 41: 46-67, 1987.

26) Collins, D. A., Becks, M. E., Simpson, M. E. and Evans, H. M.: Growth and transformation of the mandibular joint in the rat. Am. J. Orthodont. Oral Surg. 32: 431-442, 1946.

27) Weinreb, M., Gazit, E. and Weinreb, M. M.: Mandibular growth and histologic changes in condylar cartilage of rats intoxicated with vitamin $\mathrm{D}_{3}$ or $1,25(\mathrm{OH})_{2} \mathrm{D}_{3}$ and pair-fed (undernourished) rats. J. Dent. Res. 65 : 1449-1452, 1986.

28) Hurley, L. S., Gowan, J. and Milhaud, G.: Calcium metabolism in manganese-deficient and zincdeficient rats. Proc. Soc. Exp. Biol. Med. 130: 856-860, 1969.

29) Fujimoto, M.: Scanning electron microscopy of calcification of cartilage matrix in the mandibular condyle. J. Jpn. Oral Biol. 24: 62-71, 1982.

30) Boyde, A. and Jones, S. J.: Scanning electron microscope studies of the formation of mineralized tissues. In: Developmental aspects of oral biolosy (ed. by Slavkin, H. C. and Vavetta, L. A.). 1st ed., Academic Press, New York and London, 1972, 270, 272-273.

31) Suzuki, I., Goto, K., Goto, S. and Takiuchi, R.: Scanning electron microscopy of the osteocyte lacunar wall. J. Jpn. Oral Biol. $21: 622-628,2979$.

32) Shioda, S., Kadono, H., Minami, E. and Ono, T.: A scanning electron microscopic study on the mandibular condyle of rat. J. Jpn. Oral Surg. $26: 42-48,1980$.

33) Taniguchi, Y.: Ultrastructural study of formative bone surface. J. Osaka Odont. Soc. 44: 125-137. 1981. 


\title{
成長期の下顎頭軟骨へ及ぼす亜鉛の影響
}

\author{
井手口博 - 戴文 瑜 - 西田郁子 \\ 森 本彰子・西岡孝浩
}

九州歯科大学小児歯科学講座（指導：木村光孝教授）

ヒトの幼児期に相当する生後 5 週令のWistar 系雄 ラットを用い，亜鉛が成長発育期の軟骨内骨化による骨 形成に及ぼす影響について検索した。

本研究では，成長発育期の骨形成において带鉛の影響 を調べるために亜鉛含有量の異なる食䬣を与え，その影 響をラットの下顎頭軟骨を用いを用いて検索した。

実験には小児期に相当する生後 5 週龄の Wistar 系雄 ラット (40匹)を用い, 無作為に次の 4 群に分けた.

対照群(標準食)：ラット標準飼料(オリエンタル醉母 工業)と水道水にて飼育した。

亜鉛欠乏食群：亜鉛欠乏飼料(オリェンタル酵母工業)
と水道水で飼育した.

低亜鉛食群 $(50 \%$ )：低亜鉛食飼料(オリエンタル酵母 工業) と水道水で飼育した。

高亜鉛食群 $(150 \%)$ ：高亜鉛食飼料(オリエンタル酵 母工業) と水道水で飼育した。

骨塩量, $\mathrm{Ca}, \mathrm{P}$ の定量分析, 病理組織所見ならびに走 查型電顕所見より総合的に判断して, 成長期の下顎頭軟 骨は骨形成において亜鉛が必要不可欠な微量元素であ り，さらに亜鉛摄取量を増加させることにより骨形成作 用を促進されることが示唆された. 